\title{
Progesterone production in vitro by small and large ovine luteal cells
}

\author{
R. J. Rodgers, J. D. O'Shea and J. K. Findlay* \\ Department of Veterinary Preclinical Sciences, University of Melbourne, Parkville, Victoria 3052, \\ and ${ }^{*}$ Medical Research Centre, Prince Henry's Hospital, Melbourne, Victoria 3004, Australia
}

\begin{abstract}
Summary. Corpora lutea from cyclic ewes were dissociated by collagenase digestion and trypsin/EGTA treatment. Enriched fractions of endothelial cells, small luteal cells and large luteal cells were prepared on a stepped gradient of Ficoll 400. Progesterone was measured by radioimmunoassay and the results corrected so that progesterone production by each cell type could be determined. Endothelial cells did not produce significant amounts of progesterone, with or without LH stimulation, and endothelial cell contamination of small and large luteal cell fractions did not influence progesterone production by these fractions. Mean \pm s.e.m. basal progesterone production $(n=10)$ by large luteal cells was greater $(P<0.001)$ on a per cell basis than that by small luteal cells $(1.16 \pm 0.16$ compared with $0.25 \pm 0.06 \mathrm{pg} / \mathrm{h} /$ cell $)$. However $\mathrm{LH}$, which stimulated a maximal 3-4-fold increase in progesterone production by small luteal cells $\left(\mathrm{LH} \mathrm{ED} \mathrm{D}_{50}=0 \cdot 14 \mathrm{ng} / \mathrm{ml}\right)$, had no significant effect on production by large luteal cells, when contamination by small luteal cells was taken into account. The response of small luteal cells was specific to $\mathrm{LH}$, other hormones having had no significant effect.

Basal progesterone production by small luteal cells $\left(0.12 \pm 0.03 \mathrm{fg} / \mathrm{h} / \mu^{3}\right)$ calculated per unit volume of cell was not significantly different from that of large luteal cells $\left(0.17 \pm 0.02 \mathrm{fg} / \mathrm{h} / \mu^{3} \mathrm{~m}^{3}\right)$. After $\mathrm{LH}$ stimulation, small luteal cells produced more progesterone than did large luteal cells $(0.40 \pm 0.09$ compared with $0.18 \pm 0.03$ $\left.\mathrm{fg} / \mathrm{h} / \mu^{3}\right)(P<0.05)$. When the amounts of progesterone produced per cell were multiplied by the absolute numbers of large luteal $\left(1 \times 10^{7}\right)$ and small luteal $\left(5 \times 10^{7}\right)$ cells in the intact corpus luteum, basal progesterone production by large luteal cells $(11.6 \pm 1.6 \mu \mathrm{g} / \mathrm{h})$ was similar to that by small luteal cells $(12.3 \pm 3.0 \mu \mathrm{g} / \mathrm{h})$. However, under LH stimulation, progesterone production by the small luteal cell type $(39.9 \pm 9.5$ $\mu \mathrm{g} / \mathrm{h})$ was $\sim 3$ times greater than that by the large luteal cell type $(12.3 \pm 1.6 \mu \mathrm{g} / \mathrm{h})(P<$ $0 \cdot 05)$.
\end{abstract}

We therefore conclude that small luteal cells may be the principal source of luteal progesterone production in the sheep.

\section{Introduction}

The corpus luteum (CL) of the sheep, like that of many other species, contains two types of luteal cell, small and large, which are believed to be derived from the theca and granulosa cells respectively of the ovarian follicle (Mossman \& Duke, 1973; O'Shea, Cran \& Hay, 1980). For a number of reasons the large luteal cell has been widely assumed to be the major source of luteal progesterone (see Rothchild, 1981). Firstly, it is the most prominent cell in an endocrine gland whose major hormone is progesterone. Secondly, granulosa cells from ovine follicles can produce 
progesterone in vitro (Moor, 1977). Thirdly, granules postulated to contain progesterone (Gemmell, Stacy \& Thorburn, 1974; Sawyer, Abel, McClellan, Schmitz \& Niswender, 1979) are found almost exclusively in the large luteal cells (O'Shea et al., 1979). Fourthly, in-vitro evidence from CL of pigs (Lemon \& Loir, 1977), cattle (Ursely \& Leymarie, 1979; Koos \& Hansel, 1981) and sheep (Fitz, Mayan, Sawyer \& Niswender, 1982; Rodgers \& O'Shea, 1982) has shown that the large luteal cells produce more progesterone per cell than do small luteal cells. The small luteal cell has been less studied. However, small luteal cells from the CL of pigs (Lemon \& Loir, 1977), cattle (Ursely \& Leymarie, 1979; Koos \& Hansel, 1981) and sheep (Fitz et al., 1982; Rodgers \& O'Shea, 1982), also produce progesterone in vitro, and in all these species have been shown to be more responsive than large luteal cells to luteinizing hormone (LH). Furthermore, it has been estimated that there are 3-5 times more small luteal than large luteal cells in CL of pregnant (O'Shea et al., 1979) and cyclic (Rodgers, O'Shea \& Bruce, 1983a) ewes. We have therefore analysed the relative contributions of the two types of luteal cell from the ovine CL to progesterone production. Some details of this work have been reported briefly by Rodgers, O’Shea \& Findlay (1982).

\section{Materials and Methods}

\section{Purification and incubation of cells}

The method for preparing fractions of endothelial, small luteal and large luteal cells from ovine CL has been reported in detail by Rodgers \& O'Shea (1982). Briefly, ovaries were obtained at an abattoir from cyclic ewes within $15 \mathrm{~min}$ of death and transported to the laboratory. Fully developed $\mathrm{CL}$, which showed no histological signs of regression, were selected. The tissues were initially dissociated in collagenase ( $400 \mathrm{U} / \mathrm{ml}$; type $1 \mathrm{~A}$; Sigma Chemical Co., St Louis, Missouri, U.S.A.) in Dulbecco modified Eagle's medium (DMEM) $(10 \mathrm{ml} / \mathrm{g}$ luteal tissue) and further dissociated into a single cell suspension by $0.3 \%$ trypsin $/ 1 \mathrm{~mm}$-ethyleneglycol-bis-( $\beta$-aminoethyl-ether $) N, N^{\prime}$-tetracetic acid (EGTA) treatment. The incubation was terminated by the addition of soybean trypsin inhibitor.

Enriched fractions of endothelial cells (including pericytes), small luteal cells and large luteal cells were prepared on a stepped gradient of Ficoll 400 (Pharmacia Fine Chemicals, Uppsala, Sweden). For each CL, an aliquant of cells from each fraction was counted in a haemocytometer after dilution with trypan blue (Phillips, 1973). The yield of viable cells (those excluding trypan blue) was determined and the cells were classified on the basis of cell diameter. Generally, a pure fraction of endothelial cells was obtained, but endothelial cells were always contaminants of luteal cell fractions. Fractions of small luteal cells were relatively free of large luteal cells, but large luteal cell fractions did contain some small luteal cells (Table 1). The yield of cells and the degree of purity

Table 1. The mean composition (\% of total cells) of the small and large luteal fractions used from $16 \mathrm{CL}$ in the present experiments

\begin{tabular}{cccc}
\hline \multirow{2}{*}{$\begin{array}{c}\text { Cell } \\
\text { fraction }\end{array}$} & $\begin{array}{c}\text { Endothelial } \\
\text { cells }\end{array}$ & $\begin{array}{c}\text { Small luteal } \\
\text { cells }\end{array}$ & $\begin{array}{c}\text { Large luteal } \\
\text { cells }\end{array}$ \\
\cline { 2 - 4 } Small luteal cell & $36 \cdot 0$ & $60 \cdot 8$ & $3 \cdot 2$ \\
Large luteal cell & $(34 \cdot 3-37 \cdot 7) \dagger$ & $(58 \cdot 9-62 \cdot 7)$ & $(0-7 \cdot 8)$ \\
& $32 \cdot 9$ & $21 \cdot 7$ & $45 \cdot 5$ \\
& $(31 \cdot 3-34 \cdot 5)$ & $(19 \cdot 2-24 \cdot 0)$ & $(43 \cdot 9-47 \cdot 0)$ \\
\hline
\end{tabular}

* Cells classified according to size in a haemocytometer: endothelial cells $<14 \mu \mathrm{m}$, small luteal cells $14-19 \mu \mathrm{m}$, and large luteal cells $>19 \mu \mathrm{m}$ (Rodgers \& O'Shea, 1982).

$\dagger$ (Mean minus s.e.m. - mean plus s.e.m.). 
of each cell fraction varied between CL, hence results were often analysed within CL and are generally shown for only $1 \mathrm{CL}$.

Incubations of cells in DMEM containing $10 \%$ fetal calf serum (Flow Laboratories Inc., Virginia, U.S.A.) were carried out in triplicate or quadruplicate in 24-well plates (Flow Laboratories Inc.) ( $1 \mathrm{ml}$ per well) at $37^{\circ} \mathrm{C}$ in a humidified atmosphere of $5 \% \mathrm{CO}_{2}$ in air. Preliminary experiments showed that cells had adhered to the bottom of the well within $1 \mathrm{~h}$. Incubations were terminated by freezing $\left(-20^{\circ} \mathrm{C}\right)$ the samples.

\section{Progesterone radioimmunoassay}

Progesterone was measured either in incubation media alone, or in incubation media containing cells after sonication. Total progesterone release was defined as all that progesterone released into the medium during the period of incubation. Net progesterone production was defined as the amount of progesterone present in the cells and medium at the end of an incubation less the amount present at the start.

Progesterone was measured by the method of Hossain, Lee, Clarke \& O'Shea (1979). Antiserum raised in a sheep against progesterone-11-hemisuccinate-BSA was obtained from the Hormone Assay Development Group (C.S.I.R.O., Prospect, New South Wales, Australia): significant crossreactants were 11-hydroxyprogesterone $(27 \%)$, 11-deoxycorticosterone $(6.9 \%)$ and corticosterone $(5.8 \%)$. All other steroids tested, including $20 \alpha$-dihydroprogesterone, showed cross-reactivity of $<1.0 \%$. Tritiated progesterone $\left(\left[1,2,6,7-{ }^{3} \mathrm{H}\right]\right.$ progesterone, sp. act. $\left.3.3 \times 10^{12} \mathrm{~Bq} / \mathrm{mmol}\right)$ was obtained from Amersham International, Buckinghamshire, U.K., and unlabelled progesterone standard from Sigma.

Antiserum $(100 \mu \mathrm{l}$, initial dilution $1 / 3000)$ and $\left[{ }^{3} \mathrm{H}\right]$ progesterone $(100 \mu \mathrm{l}, 30 \mathrm{pg} /$ tube $)$ were added

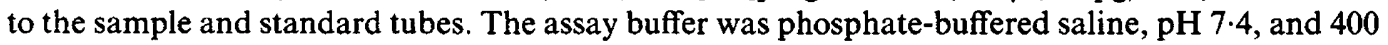
$\mu l$ assay buffer containing $5 \mu \mathrm{l}$ incubation medium were added to each standard tube. An aliquant $(400 \mu \mathrm{l})$ of unextracted sample was added to each sample tube after appropriate dilution in assay buffer and incubation medium. The tubes were incubated overnight at $4^{\circ} \mathrm{C}$. Free and bound hormone were separated by the addition of $100 \mu \mathrm{l}$ charcoal $(0.6 \%)$, coated with dextran $(0.06 \%)$, in suspension. After centrifugation the supernatants were decanted into vials for counting.

In validating the assay for unextracted samples, it was shown that the binding of labelled progesterone in the presence of multiple dilutions of unextracted medium in which small luteal cells and large luteal cells had been incubated was parallel to that of medium with added progesterone standard. The slopes of the linear regression of $B / B_{0} \times 100$ versus $\log$ (dilution of stock) were $-49.91,-49.68$ and -48.33 for progesterone standard, small luteal cells and large luteal cells respectively. The standard curves with amounts of incubation medium varying from 1 to $20 \mu l$ per tube were identical. Hence all samples diluted with assay buffer contained between 1 and $20 \mu l$ incubation medium.

Assay results were calculated by the method of Burger, Lee \& Rennie (1972). The sensitivity of the assay was $3 \mathrm{pg} /$ tube and the mean \pm s.e.m. within-assay coefficient of variation was $7 \cdot 2 \pm 0 \cdot 1 \%$ at $86 \mathrm{pg} /$ tube ( 23 assays). All the samples from each CL were measured within the same assay except in one experiment (on effect of renewal of medium on progesterone production), in which 4 assays were used. The mean between-assay coefficient of variation of these 4 assays was $16 \cdot 1 \%$.

\section{Hormone preparations}

The following hormones were donated by the National Institute of Arthritis, Metabolism and Digestive Diseases, NIH, Bethesda, Maryland, U.S.A. : ovine LH (No. 21, biopotency 2.5 times NIH-LH-S1), ovine FSH (No. 13, oLH contamination 0.05 times NIH-LH-S1), ovine prolactin (NIH-P-S13, <0.1\% LH contamination by weight) and ovine growth hormone (NIH-GH-S1 1, LH contamination $<0.25 \%$ NIH-LH-S1). Ovine placental lactogen was purified from placental 
cotyledons by the method of Chan, Robertson \& Friesen (1976), and kindly donated by Dr M. J. Waters, University of Queensland, St Lucia, Australia. Ovine placental lactogen had $78 \%$ of the potency of human GH (NIH clinical grade, batch HS 2019) in binding to a rabbit liver membrane preparation and gave one major and one minor band on alkaline polyacrylamide gel electrophoresis using a Tris/borate/sulphate buffer of $\mathrm{pH} \mathrm{9.0,} \mathrm{the} \mathrm{major} \mathrm{band} \mathrm{corresponding} \mathrm{to} \mathrm{ovine} \mathrm{placental}$ lactogen activity in the radioreceptor assay (M. J. Waters, personal communication). Human GH (clinical grade, batch 046-1) was obtained from the Commonwealth Serum Laboratories, Melbourne, Australia. Dibutyryl cyclic AMP and the phosphodiesterase inhibitor, 1-isobutyl-3methylxanthine (MIX), were obtained from Sigma.

\section{Statistical analyses}

Most data were analysed within CL by Student's $t$ test. When comparisons were made involving many CL, paired $t$ tests were used. Regressional analysis was carried out by the least squares method (Sokal \& Rohlf, 1969) and s.e.m. of percentages were calculated using the arcsine transformation.

\section{Results}

Effects of concentration of LH on progesterone production by luteal cells

Small and large luteal cell fractions were incubated for $12 \mathrm{~h}$ with various doses of LH (3-200 $\mathrm{ng} / \mathrm{ml}$ for $4 \mathrm{CL}$ and $0.05-100 \mathrm{ng} / \mathrm{ml}$ for another $4 \mathrm{CL}$ ). Results from a representative $\mathrm{CL}$ are shown in Text-fig. 1. There was net synthesis of progesterone during incubation of both cell fractions. Small luteal cell fractions responded maximally to $\mathrm{LH}$ with a 3-4-fold increase in progesterone production even at doses as low as $3 \mathrm{ng} / \mathrm{ml}$. At lower doses of $\mathrm{LH}$ the response was dose-dependent with a mean \pm s.e.m. ED $_{50}$ of $0.14 \pm 0.04 \mathrm{ng} / \mathrm{ml}(4 \mathrm{CL})$. In large luteal cell fractions, basal progesterone production was greater than that in small luteal cell fractions, but the response to LH

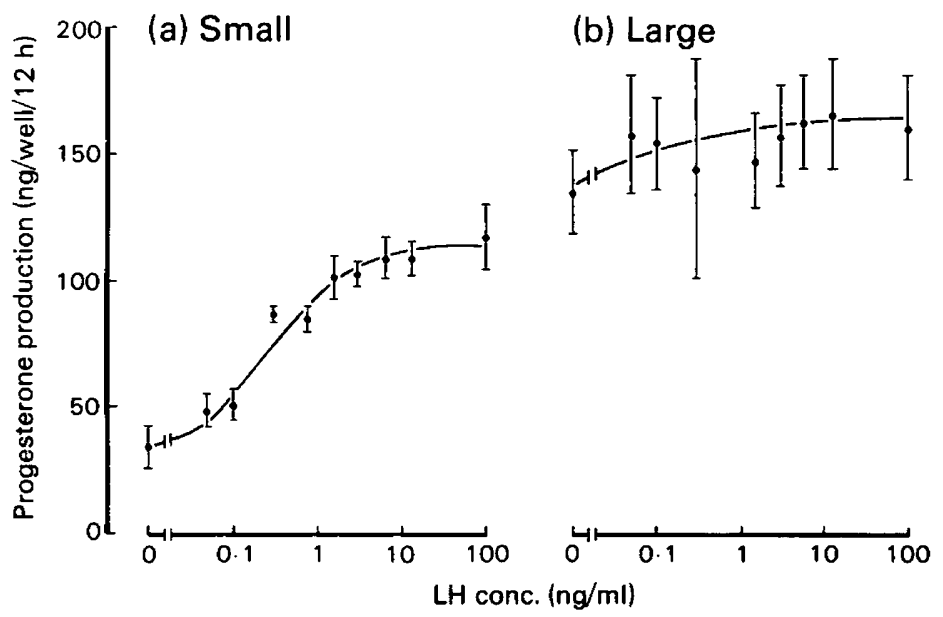

Text-fig. 1. Net progesterone production (mean \pm s.d.) by (a) small and (b) large luteal cell fractions incubated with various doses of LH for $12 \mathrm{~h}$ (single CL, triplicate determinations). Progesterone levels at the start of the incubation were 0.7 and $4.1 \mathrm{ng} /$ well and the number of viable luteal cells per well was $1.08 \times 10^{4}$ and $0.78 \times 10^{4}$ for small and large luteal cell fractions respectively. 
was not as dramatic and reflected the degree of contamination with small luteal cells. For most subsequent experiments an LH dose of $100 \mathrm{ng} / \mathrm{ml}$ was selected to ensure a maximal response by the luteal cells.

\section{Effects of endothelial cells on progesterone production}

As endothelial cells contaminated fractions of small luteal and large luteal cells (Table 1), the ability of endothelial cells to produce progesterone in vitro and to influence that produced by small and large luteal cells was examined. Basal and maximally LH-stimulated $(100 \mathrm{ng} / \mathrm{ml})$ progesterone production was measured in endothelial, small luteal and large luteal cell fractions from 4 CL incubated for $12 \mathrm{~h}$. In addition, progesterone production was measured in small and large luteal cell fractions to which endothelial cells were added. Results for a representative $C L$ are shown in Table 2.

Table 2. Net basal and LH-stimulated progesterone production (mean $\pm \mathrm{s}$.d.) during a $12 \mathrm{~h}$ incubation of fractions of endothelial cells, and small and large luteal cell fractions, with $(+)$ or without $(-)$ excess endothelial cells (single CL, triplicate determinations), and the number of cells per well of each type

\begin{tabular}{|c|c|c|c|c|c|}
\hline & \multicolumn{5}{|c|}{ Net progesterone production (ng/well) } \\
\hline & \multirow{2}{*}{$\begin{array}{c}\text { Endothelial } \\
\text { cell } \\
\text { fraction }\end{array}$} & \multicolumn{2}{|c|}{$\begin{array}{l}\text { Small luteal cell } \\
\text { fraction }\end{array}$} & \multicolumn{2}{|c|}{$\begin{array}{l}\text { Large luteal cell } \\
\text { fraction }\end{array}$} \\
\hline & & - & + & - & + \\
\hline \multicolumn{6}{|c|}{$\mathrm{LH}$ conc. $(\mathrm{ng} / \mathrm{ml})$} \\
\hline $\begin{array}{r}0 \\
100\end{array}$ & $\begin{array}{l}1.0 \pm 0.1 \\
1.9 \pm 0.4\end{array}$ & $\begin{array}{r}31 \cdot 2 \pm 1 \cdot 6 \\
108 \cdot 4 \pm 7 \cdot 2\end{array}$ & $\begin{array}{l}28.6 \pm 2.0 \\
99.5 \pm 1.7\end{array}$ & $\begin{array}{l}138.9 \pm 31.2 \\
173.7 \pm 7.6\end{array}$ & $\begin{array}{l}113.1 \pm 5 \cdot 1 \\
153.7 \pm 9.9\end{array}$ \\
\hline \multicolumn{6}{|c|}{ Cell type (no. $\times 10^{4} /$ well) } \\
\hline $\begin{array}{l}\text { Endothelial } \\
\text { Small luteal } \\
\text { Large luteal }\end{array}$ & $\begin{array}{c}30 \cdot 6 \\
0 \cdot 18 \\
0\end{array}$ & $\begin{array}{l}3 \cdot 30 \\
2 \cdot 55 \\
0 \cdot 26\end{array}$ & $\begin{array}{l}33 \cdot 9 \\
2 \cdot 73 \\
0 \cdot 26\end{array}$ & $\begin{array}{l}1 \cdot 97 \\
0 \cdot 39 \\
1 \cdot 28\end{array}$ & $\begin{array}{l}32 \cdot 6 \\
0.57 \\
1.28\end{array}$ \\
\hline
\end{tabular}

Endothelial cell fractions, with or without $\mathrm{LH}$, produced little progesterone, and the absolute amounts produced were within a range which could have been explained by the small amount of contamination of these fractions by small luteal cells. There was therefore no evidence of progesterone production by endothelial cells. The amounts of progesterone produced in small or large luteal cell fractions to which endothelial cells were added were not significantly different from those produced by control fractions without added endothelial cells $(P>0.05)$. Endothelial cell contamination was therefore unlikely to have influenced the quantity of progesterone produced by small and large luteal cell fractions in these experiments.

\section{Time course of progesterone production}

Basal and maximally LH-stimulated progesterone production (expressed as progesterone concentration per well) were measured in small and large luteal cell fractions from $4 \mathrm{CL}$, incubated for $3,6,12,24$ or $48 \mathrm{~h}$ without renewal of medium. Results from a representative CL are shown in Text-fig. 2. Basal and LH-stimulated progesterone production by both cell fractions was linear for at least $6 \mathrm{~h}$ in all $\mathrm{CL}$, and up to $12 \mathrm{~h}$ in some. Production continued for at least $48 \mathrm{~h}$.

\section{Effect of renewal of medium on progesterone production}

Small and large luteal cell fractions from $2 \mathrm{CL}$ were incubated with or without $\mathrm{LH}(100 \mathrm{ng} / \mathrm{ml})$ in the medium for $48 \mathrm{~h}$ with the medium being renewed every $12 \mathrm{~h}$. The time course of the total 


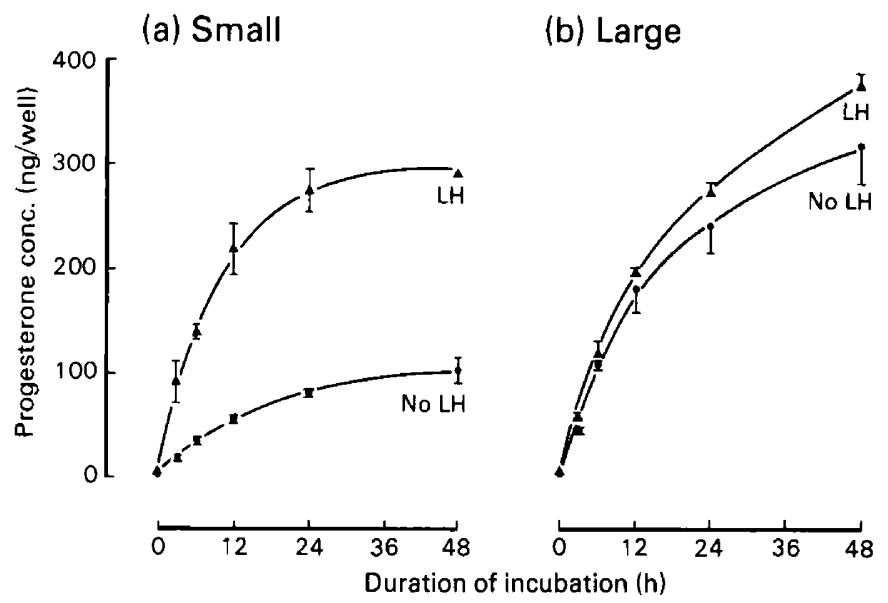

Text-fig. 2. Progesterone concentration in cells plus medium (mean \pm s.d.) during incubations for different times of (a) small and (b) large luteal cell fractions incubated with or without $\mathrm{LH}$ $(100 \mathrm{ng} / \mathrm{ml})$ (single CL, triplicate determinations). The number of viable luteal cells per well was $1.39 \times 10^{4}$ and $1.19 \times 10^{4}$ for small and large luteal cell fractions respectively.

amount of progesterone released into the medium is shown for a single CL in Text-fig. 3. Renewal of the medium did not prevent the decline in the rate of basal and LH-stimulated progesterone release (compare with another CL in Text-fig. 2 for which the medium was not renewed).

Small and large luteal cell fractions from the same $2 \mathrm{CL}$ as above were incubated for $12 \mathrm{~h}$, with or without the medium being renewed at $6 \mathrm{~h}$, or for $48 \mathrm{~h}$ with or without the medium being renewed every $12 \mathrm{~h}$. The total amount of progesterone released into the medium when the medium was renewed or not renewed during the incubation is shown in Table 3. Renewal of the medium failed to alter the amount of progesterone released by small and large luteal cell fractions, with or without LH.

(a) Small

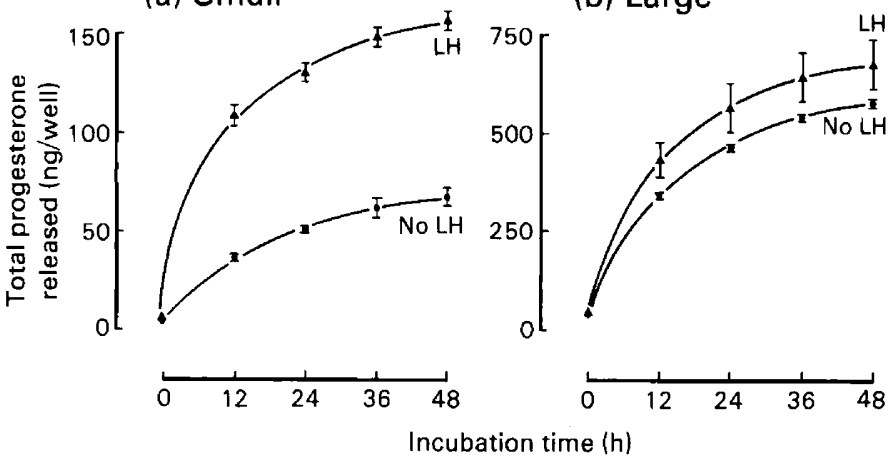

Text-fig. 3. Basal and $\mathrm{LH}$-stimulated $(100 \mathrm{ng} / \mathrm{ml})$ total progesterone released into the medium (mean \pm s.d.) by (a) small and (b) large luteal cell fractions during incubation, with renewal of the medium every $12 \mathrm{~h}$ (single CL, triplicate determinations). The number of viable luteal cells per well was $2.82 \times 10^{4}$ and $2.55 \times 10^{4}$ for small and large luteal cell fractions respectively. 
Table 3. Basal and $\mathrm{LH}$-stimulated $(100 \mathrm{ng} / \mathrm{ml})$ release of progesterone (mean $\pm \mathrm{s}$.d.) into the medium by small and large luteal cell fractions, with or without renewal of the medium during incubation (single CL, triplicate determinations)

\begin{tabular}{|c|c|c|c|c|c|}
\hline \multirow{3}{*}{$\begin{array}{l}\text { Duration } \\
\text { of } \\
\text { incubation } \\
\text { (h) }\end{array}$} & \multirow{3}{*}{$\begin{array}{l}\text { Time of } \\
\text { medium } \\
\text { renewal } \\
\text { (h) }\end{array}$} & \multicolumn{4}{|c|}{ Total progesterone released (ng/well) } \\
\hline & & \multicolumn{2}{|c|}{$\begin{array}{l}\text { Small luteal cell } \\
\text { fraction* }\end{array}$} & \multicolumn{2}{|c|}{$\begin{array}{l}\text { Large luteal cell } \\
\text { fraction } \dagger\end{array}$} \\
\hline & & $-\mathrm{LH}$ & $+\mathrm{LH}$ & $-\mathrm{LH}$ & $+\mathrm{LH}$ \\
\hline \multirow{2}{*}{12} & - & $15 \cdot 3 \pm 0 \cdot 5$ & $47 \cdot 4 \pm 1 \cdot 4$ & $78.6 \pm 11 \cdot 6$ & $93 \cdot 3 \pm 1 \cdot 8$ \\
\hline & 6 & $17 \cdot 1 \pm 1 \cdot 1$ & $42.8 \pm 4.0$ & $87.0 \pm 0.5$ & $102.5 \pm 3.7$ \\
\hline \multirow{2}{*}{48} & - & $29 \cdot 1 \pm 1 \cdot 4$ & $58 \cdot 8 \pm 4 \cdot 5$ & $187 \cdot 1 \pm 8.6$ & $177.9 \pm 20.7$ \\
\hline & $12,24, \& 36$ & $21.7 \pm 3.4$ & $59.7 \pm 5 \cdot 0$ & $170.4 \pm 11.4$ & $175 \cdot 2 \pm 6 \cdot 1$ \\
\hline
\end{tabular}

$* 0.95 \times 10^{4}$ luteal cells/well.

$+0.98 \times 10^{4}$ luteal cells/well.

\section{Effects of cell plating density on progesterone production}

Small and large luteal cell fractions from $4 \mathrm{CL}$ were incubated for $12 \mathrm{~h}$ at various plating densities with or without $\mathrm{LH}(100 \mathrm{ng} / \mathrm{ml})$. Progesterone production by cells from a representative $\mathrm{CL}$ at 4 plating densities is shown in Text-fig. 4 . There was a direct linear relationship between the number of small or large luteal cells incubated and the basal and LH-stimulated progesterone production (linear regression, $P<0 \cdot 05$ ). Thus in all other experiments (see individual legends) the numbers of cells incubated were well within the limits where cell numbers were directly proportional to progesterone production.

\section{Specificity of effect of $\mathrm{LH}$ on progesterone production}

The effects of 5 protein hormones at concentrations equimolar to $6 \mathrm{ng} \mathrm{LH} / \mathrm{ml}$ (a concentration at which LH produced near-maximal stimulation of progesterone production; Text-fig. 1) were compared with those of LH and with basal progesterone production (control) in 4 CL during a $12 \mathrm{~h}$

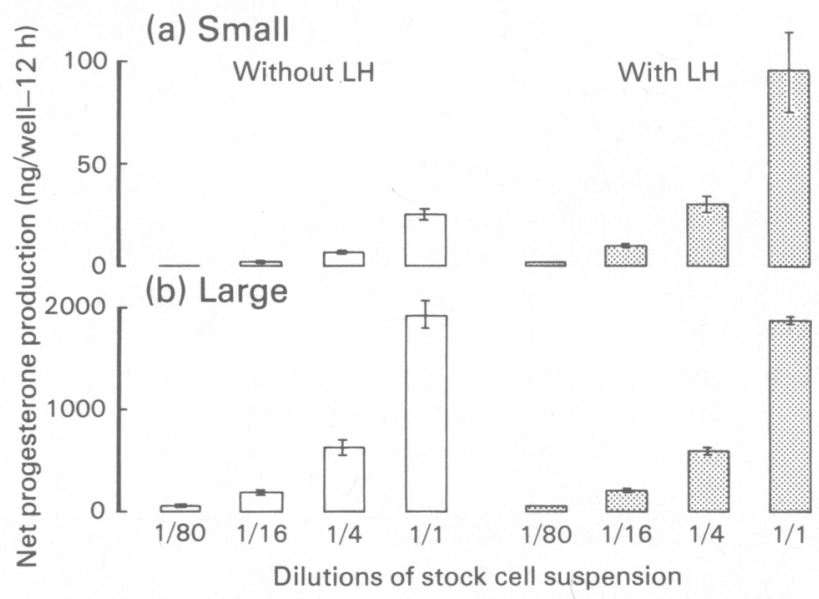

Text-fig. 4. Net basal and LH-stimulated $(100 \mathrm{ng} / \mathrm{ml})$ progesterone production (mean \pm s.d.) by (a) small and (b) large luteal cell fractions incubated for $12 \mathrm{~h}$ at various cell plating densities (single CL, triplicate determinations). Total viable luteal cells per well for stocks of small and large luteal cell suspensions were $5.40 \times 10^{4}$ and $14.1 \times 10^{4}$ respectively. 
incubation. The molecular weights of ovine LH and ovine FSH were assumed to be 30000 , and of ovine prolactin, placental lactogen and $\mathrm{GH}$, and human $\mathrm{GH}$, to be 21000 . Results from a representative $\mathrm{CL}$ are shown in Text-fig. 5. Small luteal cell fractions responded by an increase in progesterone production only to $\mathrm{LH}$ in all $4 \mathrm{CL}$. Neither $\mathrm{LH}$ nor any other hormone used produced any significant alteration in progesterone production by large luteal cell fractions. At higher equimolar doses ( $200 \mathrm{ng} / \mathrm{ml}$ for oLH and oFSH and $140 \mathrm{ng} / \mathrm{ml}$ for oPRL, oPL, oGH and hGH) oFSH and oGH also stimulated increases in progesterone production by small luteal cell fractions, to levels $50-100 \%$ of those resulting from $\mathrm{LH}$ stimulation (4 CL, data not shown). However, as the $\mathrm{LH} \mathrm{ED}_{50}$ was $0.14 \mathrm{ng} / \mathrm{ml}$ these results could have been due to LH contamination of these pituitary hormone preparations (see 'Materials and Methods').

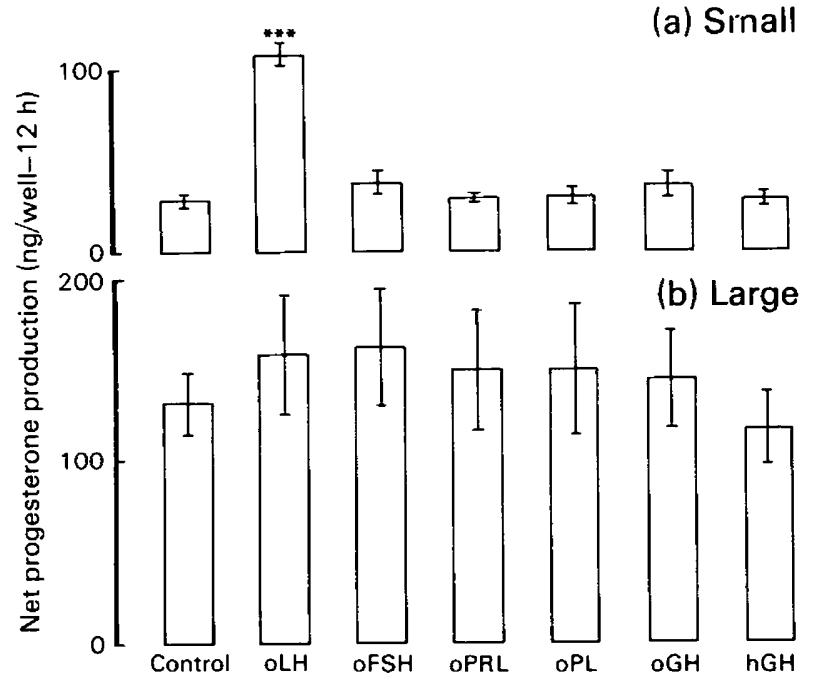

Text-fig. 5. Net progesterone production (mean \pm s.d.) by (a) small and (b) large luteal cell fractions incubated in the presence of various protein hormones: $\mathrm{LLH}$ and $\mathrm{oFSH}$ at $6 \mathrm{ng} / \mathrm{ml}$ and oPRL, oPL, oGH and $\mathrm{hGH}$ at $4.2 \mathrm{ng} / \mathrm{ml}$ (single CL, quadruplicate determinations). The total numbers of viable luteal cells per well were $1.08 \times 10^{4}$ and $0.70 \times 10^{4}$ for small and large luteal cell fractions respectively. ${ }^{* * *} P<0.001$ compared with control value.

\section{Effects of dibutyryl cAMP on progesterone production}

Small and large luteal cell fractions from $7 \mathrm{CL}$ were incubated for $12 \mathrm{~h}$ with $0.5 \mathrm{mM}-\mathrm{MIX}, 3 \mathrm{mM}$ dibutyryl cAMP in $0.5 \mathrm{mM}-\mathrm{MIX}$, or $100 \mathrm{ng} \mathrm{LH} / \mathrm{ml}$, to determine whether the lack of responsiveness of large luteal cells to LH may have been due to receptor damage during cell purification. At the dosage used, dibutyryl cAMP in the presence of MIX stimulated a slightly greater increase in progesterone production (Table 4) than did LH $(0.05<P<0.06$ for small luteal cell fractions; $P<$ 0.01 for large luteal cell fractions, paired $t$ tests). The response to inhibition of phosphodiesterase with MIX treatment was intermediate between that of dibutyryl cAMP and LH. However, small luteal cell fractions were still considerably more responsive to dibutyryl cAMP stimulation than were large luteal cell fractions, suggesting that the comparative unresponsiveness of large luteal cells to LH was not due to differential LH-receptor damage.

\section{Comparison of the capacity of small and large luteal cells to produce progesterone}

Calculated basal and maximally LH-stimulated $(100 \mathrm{ng} / \mathrm{ml})$ progesterone production per cell, per unit volume of cell, and per cell type are shown in Table 5 . On a per cell basis, basal production 
Table 4. Net progesterone production (mean \pm s.e.m.) by small and large luteal cell fractions from $7 \mathrm{CL}$ incubated for $12 \mathrm{~h}$ with 1-isobutyl-3-methylxanthine (MIX), dibutyryl cAMP or LH

\begin{tabular}{lccc}
\hline & \multicolumn{3}{c}{$\begin{array}{c}\text { Net progesterone production } \\
(\% \text { of basal production }=100 \%)\end{array}$} \\
\cline { 2 - 4 } $\begin{array}{c}\text { Cell } \\
\text { fraction }\end{array}$ & $\begin{array}{c}\text { MIX } \\
(0.5 \mathrm{mM})\end{array}$ & $\begin{array}{c}\text { Dibutyryl cAMP } \\
(3 \mathrm{mM} \text { in } 0.5 \mathrm{mM}-\mathrm{MIX})\end{array}$ & $\begin{array}{c}\mathrm{LH} \\
(100 \mathrm{ng} / \mathrm{ml})\end{array}$ \\
\hline $\begin{array}{c}\text { Small luteal } \\
\text { cell }\end{array}$ & $183 \pm 16$ & $401 \pm 54$ & $353 \pm 44$ \\
$\begin{array}{c}\text { Large luteal } \\
\text { cell* }\end{array}$ & $129 \pm 14$ & $158 \pm 15$ & $117 \pm 5$ \\
\hline
\end{tabular}

* Progesterone production not corrected for contamination by small luteal cells.

Table 5. Mean \pm s.e.m. rates of net basal and $\mathrm{LH}$-stimulated $(100 \mathrm{ng} / \mathrm{ml})$ progesterone production per cell, per unit volume of cell, and per cell type for small and large luteal cell fractions from $10 \mathrm{CL}$

\begin{tabular}{|c|c|c|c|c|}
\hline & \multicolumn{4}{|c|}{ Net progesterone production } \\
\hline & \multicolumn{2}{|c|}{ Basal } & \multicolumn{2}{|c|}{ LH-stimulated } \\
\hline & $\begin{array}{l}\text { Small luteal } \\
\text { cells }\end{array}$ & $\begin{array}{l}\text { Large luteal } \\
\text { cells } \dagger\end{array}$ & $\begin{array}{l}\text { Small luteal } \\
\text { cells }\end{array}$ & $\begin{array}{l}\text { Large luteal } \\
\text { cells } \dagger\end{array}$ \\
\hline Per cell ( $\mathrm{pg} / \mathrm{h} /$ cell $)$ & $0.25 \pm 0.06$ & $1 \cdot 16 \pm 0 \cdot 16^{* * *}$ & $0.80 \pm 0.19$ & $1.24 \pm 0.16$ \\
\hline $\begin{array}{l}\text { Per unit volume of cell } \\
\left(\mathrm{fg} / \mathrm{h} / \mu \mathrm{m}^{3}\right) \\
\text { Per cell type } f(\mu \mathrm{g} / \mathrm{h})\end{array}$ & $\begin{array}{l}0.12 \pm 0.03 \\
12.3 \pm 3.0\end{array}$ & $\begin{array}{l}0.17 \pm 0.02 \\
11.6 \pm 1.6\end{array}$ & $\begin{array}{l}0.40 \pm 0.09 \\
39.9 \pm 9.5\end{array}$ & $\begin{array}{l}0.18 \pm 0.03^{*} \\
12 \cdot 3 \pm 1 \cdot 6^{*}\end{array}$ \\
\hline
\end{tabular}

of progesterone by small luteal cells was less than that by large luteal cells. The same trend was maintained under LH stimulation, but differences were no longer significant. After correcting for differences in cell volume, based on values of $2.0 \times 10^{3} \mu \mathrm{m}^{3}$ and $6.9 \times 10^{3} \mu \mathrm{m}^{3}$ for small and large luteal cells respectively (Rodgers \& O'Shea, 1982), no differences between cell types were detectable in basal production, but LH-stimulated production was significantly greater by small luteal cells. When progesterone production per cell was multiplied by the mean numbers of each cell type in the CL (Rodgers et al., 1983a), basal production rates were similar, but LH-stimulated production by small luteal cells was $\sim 3$ times that of large luteal cells. The mean increase in progesterone production by large luteal cells in response to $\mathrm{LH}$ was $7 \%$ after correction for progesterone production due to small luteal cell contamination. This increase was not significant (paired $t$ test, $10 \mathrm{CL}$ ).

\section{Discussion}

The present data on progesterone production by ovine luteal cells in vitro demonstrate that (a) small luteal cells respond specifically to $\mathrm{LH}$ and not to any of the other hormones tested, including ovine prolactin and ovine placental lactogen, (b) small luteal cells are very sensitive to $L H$, with an $\mathrm{ED}_{50}$ of $0 \cdot 14 \mathrm{ng} / \mathrm{ml}$, (c) the apparent response to LH by large luteal cell fractions can be accounted for by small luteal cell contamination, and (d) the unresponsiveness of large luteal cells to LH is not likely to have been due to $\mathrm{LH}$ receptor damage during purification of cell populations. 
In the present study contamination of large luteal cell fractions with small luteal cells was higher than that reported previously (Rodgers \& O'Shea, 1982), and this contamination needs to be taken into account when interpreting the responses to $\mathrm{LH}$ by these fractions. When this was done, no significant response to LH by large luteal cells was demonstrable. In other work in the sheep (Fitz et al., 1982), fractions of large luteal cells responded to LH with a $20 \%$ increase in progesterone production which "was consistent with that amount attributable to contamination of these fractions by small luteal cells".

Artefacts associated with contamination of large luteal cell fractions with small luteal cells may also account, at least in part, for reported findings on the effects of $\mathrm{LH}$ on the large luteal cells of pigs (Lemon \& Loir, 1977) and cattle (Ursely \& Leymarie, 1979; Koos \& Hansel, 1981). In none of these studies were results corrected for contamination by the very LH-responsive small luteal cells, although contamination was shown to be considerable when cell populations were examined carefully (Koos \& Hansel, 1981). In all these species, therefore, the possibility exists that large luteal cells, at least in vitro, are incapable of responding to $\mathrm{LH}$ by increased progesterone production. It remains to be demonstrated whether large luteal cells show a similar unresponsiveness to $\mathrm{LH}$ in vivo.

Taken together, data on the amounts of progesterone produced per cell in vitro by small and large luteal cells, and the relative numbers of these two cell types in luteal tissue (Rodgers et al., 1983a), suggest the intriguing possibility that the small luteal cells of the sheep may be the principal source of progesterone in this species (see Table 5). For this to be so would require that the behaviour of the two types of luteal cell in vivo is similar to that in vitro, and that LH levels in vivo during the luteal phase of the oestrous cycle are sufficient to stimulate the small luteal cells. There is evidence in favour of the latter, in the demonstration that the $\mathrm{ED}_{50}$ for $\mathrm{LH}$ stimulation of small luteal cells $(0 \cdot 14 \mathrm{ng} / \mathrm{ml})$ is exceeded by luteal-phase plasma LH levels (mean levels of $0.7 \mathrm{ng} / \mathrm{ml}$ : Hauger, Karsch \& Foster, 1977; between pulse levels of $0.6 \mathrm{ng} / \mathrm{ml}$ and pulse levels of $3 \mathrm{ng} / \mathrm{ml}$ : Baird, Swanston \& Scaramuzzi, 1976).

Indirect evidence that the behaviour of separated luteal cells in vitro may accurately reflect events in vivo can be adduced by comparing data on the effects of administration or neutralization of LH in vivo with the findings of in-vitro studies. If in the present experiments progesterone production rates for both luteal cell types are combined, it could be predicted that luteal progesterone production could be increased by a maximum of $220 \%$ basal progesterone production under maximal LH stimulation (12.3 plus 11.6 compared with 39.9 plus $12.3 \mu \mathrm{g} / \mathrm{h}$ : see Table 5). Or conversely, the maximum amount by which progesterone production could be reduced by inactivating $\mathrm{LH}$ is $46 \%$ (given that no regressionary changes occur and that tissue weight remains constant). These values are consistent with in-vitro $\mathrm{LH}$ stimulation of luteal tissue slices (Kaltenbach, Cook, Niswender \& Nalbandov, 1967; Evrard, Leboulleux \& Hermier, 1978; Fletcher \& Niswender, 1982), in-vivo LH stimulation of luteal progesterone secretion (Collett, Land \& Baird, 1973; Niswender, Reimers, Diekman \& Nett, 1976; Suter, Fletcher, Sluss, Reichert \& Niswender, 1980), and in-vivo infusion of antiserum to LH (Niswender et al., 1976).

The present findings could also help to explain why, in contrast to oestradiol-17 $\beta$ and androstenedione, there is no significant increase in progesterone secretion from the ovary following each pulsatile release of LH in the ewe during the luteal phase (Baird et al., 1976). From the present results it could be predicted that, even if there was no $\mathrm{LH}$ in the plasma between pulsatile releases of $\mathrm{LH}$, then at best there could be a doubling in progesterone secretion in response to a pulse of $\mathrm{LH}$. If the basal $\mathrm{LH}$ level between pulses was $0.14 \mathrm{ng} / \mathrm{ml}$ (the $\mathrm{ED}_{50}$ for $\mathrm{LH}$ stimulation of small luteal cells in the present experiment) then one could predict only a $60 \%$ increase in luteal progesterone secretion. However, basal levels of $\mathrm{LH}$ between pulses have been measured at $0.6 \mathrm{ng} / \mathrm{ml}$ (Baird $e t$ $a l ., 1976$ ), at which level the small luteal cells would already be highly stimulated. Therefore, very little increase in the rate of progesterone secretion in response to a pulsatile release of $\mathrm{LH}$ would be predicted.

Many studies have associated the release of $0.2 \mu \mathrm{m}$ secretory granules from the large luteal cells 
with the secretion of progesterone, leading to the hypotheses that such granules contain progesterone (Gemmell et al., 1974; Sawyer et al., 1979), and that the limiting membrane of these granules contains receptors for $\mathrm{LH}$ which are incorporated into the cell membrane during exocytosis (Sawyer et al., 1979). The present study provides no support for these hypotheses. Firstly, the small luteal cells, which are capable of secreting progesterone and of responding to LH, are almost totally devoid of $0.2 \mu \mathrm{m}$ secretory granules (O'Shea et al., 1979). Secondly, the large luteal cells, which contain many granules, possess far fewer $\mathrm{LH}$ receptors than do small luteal cells (Fitz et al., 1982), respond little if at all to $\mathrm{LH}$, and may be subsidiary to the small luteal cells in production of progesterone. Furthermore, several lines of evidence now suggest that the $0.2 \mu \mathrm{m}$ secretory granules of large luteal cells contain oxytocin rather than progesterone: (a) large luteal cells contain and can produce oxytocin in vitro (Rodgers, O'Shea, Findlay, Flint \& Sheldrick, 1983b), (b) prostaglandin F-2 $\alpha$ and its analogues stimulate the release of oxytocin from the ovary (sheep) (Flint \& Sheldrick, 1982) and cause degranulation of the large luteal cells (cattle) (Weinstein, Heath, Shanks \& Hixon, 1982), and (c) large luteal cells, but not small luteal cells, possess high numbers of prostaglandin F-2 $\alpha$ receptors (Fitz et al., 1982).

In conclusion, it would appear that small luteal cells may be the principal source of luteal progesterone production in the sheep. Furthermore, it is questionable whether large luteal cells are capable of responding to $\mathrm{LH}$ by an increase in progesterone production. The possibility that progesterone production may not be the major function of large luteal cells needs to be given serious consideration, particularly in view of the demonstration that these cells contain and can synthesize oxytocin.

We are grateful to Dr R. I. Cox, C.S.I.R.O., Blacktown, Australia, for the provision of progesterone antisera, Dr M. J. Waters, University of Queensland, Australia, for ovine placental lactogen and the NIAMDD for purified hormone preparations. Financial support for this project was provided by the Melbourne University Veterinary Research Fund and the Australian Meat Research Committee. R.J.R. was in receipt of a Melbourne University Veterinary Research Fund Studentship.

\section{References}

Baird, D.T., Swanston, I. \& Scaramuzzi, R.J. (1976) Pulsatile release of $\mathrm{LH}$ and secretion of ovarian steroids in sheep during the luteal phase of the estrous cycle. Endocrinology 98, 1490-1496.

Burger, H.G., Lee, V.W.K. \& Rennie, G.C. (1972) A generalized computer program for the treatment of data from competitive protein-binding assays including radioimmunoassays. $J$. Lab. Clin. Med. 80, 302 312.

Chan, J.S., Robertson, H.A. \& Friesen, H.G. (1976) The purification and characterization of ovine placental lactogen. Endocrinology 98, 65-76.

Collett, R.A., Land, R.B. \& Baird, D.T. (1973) The pattern of progesterone secretion by the autotransplanted ovary of the ewe in response to ovine luteinizing hormone. J. Endocr. 56, 403-411.

Evrard, M., Leboulleux, P. \& Hermier, C. (1978) Role of prostaglandin $\mathrm{F}_{2 \alpha}$ in modulation of $\mathrm{LH}$-stimulated steroidogenesis in vitro in different types of rat and ewe corpora lutea. Prostaglandins 16, 491-502.

Fitz, T.A., Mayan, M.H., Sawyer, H.R. \& Niswender, G.D. (1982) Characterization of two steroidogenic cell types in the ovine corpus luteum. Biol. Reprod. 27, 703-711.
Fletcher, P.W. \& Niswender, G.D. (1982) Effect of PGF $2 \alpha$ on progesterone secretion and adenylate cyclase activity in ovine luteal tissue. Prostaglandins 23, 803-818.

Flint, A.P.F. \& Sheldrick, E.L. (1982) Ovarian secretion of oxytocin is stimulated by prostaglandin. Nature, Lond. 297, 587-588.

Gemmell, R.T., Stacy, B.D. \& Thorburn, G.D. (1974) Ultrastructural study of secretory granules in the corpus luteum of the sheep during the estrous cycle. Biol. Reprod. 11, 447-462.

Hauger, R.L., Karsch, F.J. \& Foster, D.L. (1977) A new concept for control of the estrous cycle of the ewe based on the temporal relationships between luteinizing hormone, estradiol and progesterone in peripheral serum and evidence that progesterone inhibits tonic LH secretion. Endocrinology 101, 807-817.

Hossain, M.I., Lee, C.S., Clarke, I.J. \& O'Shea, J.D. (1979) Ovarian and luteal blood flow, and peripheral plasma progesterone levels, in cyclic guinea-pigs. $J$. Reprod. Fert. 57, 167-174.

Kaltenbach, C.C., Cook, B., Niswender, G.D. \& Nalbandov, A.V. (1967) Effect of pituitary hormones on progesterone synthesis by ovine luteal tissue in vitro. Endocrinology 81, 1407-1409. 
Koos, R.D. \& Hansel, W. (1981) The large and small cells of the bovine corpus luteum: ultrastructural and functional differences. In Dynamics of Ovarian Function, pp. 197-203. Eds N. B. Schwartz \& M. Hunzicker-Dunn. Raven Press, New York.

Lemon, M. \& Loir, M. (1977) Steroid release in vitro by two luteal cell types in the corpus luteum of the pregnant sow. J. Endocr. 72, 351-359.

Moor, R.M. (1977) Sites of steroid production in ovine Graafian follicles in culture. J. Endocr. 73, 143-150.

Mossman, H.W. \& Duke, K.L. (1973) Comparative Morphology of the Mammalian Ovary, pp. $209-220$. University of Wisconsin Press, Madison.

Niswender, G.D., Reimers, T.J., Diekman, M.A. \& Nett, T.M. (1976) Blood flow: a mediator of ovarian function. Biol. Reprod. 14, 64-81.

O'Shea, J.D., Cran, D.G. \& Hay, M.F. (1979) The small luteal cell of the sheep. J. Anat. 128, 239-251.

O'Shea, J.D., Cran, D.G. \& Hay, M.F. (1980) Fate of the theca interna following ovulation in the ewe. Cell Tiss. Res. 210, 305-319.

Phillips, H.J. (1973) Dye exclusion tests for cell viability. In Tissue Culture: Methods and Applications, pp. 406408. Eds J. Kruse \& J. Patterson. Academic Press, London.

Rodgers, R.J. \& O'Shea, J.D. (1982) Purification, morphology, and progesterone production and content of three cell types isolated from the corpus luteum of the sheep. Aust. J. biol. Sci. 35, 441-455.

Rodgers, R.J., O'Shea, J.D. \& Findlay, J.K. (1982) In vitro synthesis of progesterone by small and larg ovine luteal cells. Proc. Aust. Soc. Reprod. Biol. 14, 27 Abstr.

Rodgcrs, R.J., O'Shea, J.D. \& Bruce, N.W. (1983a Quantitation of cells in the ovine corpus luteum. $J$ Anat. (in press).

Rodgers, R.J., O'Shea, J.D., Findlay, J.K., Flint, A.P.F \& Sheldrick, E.L. (1983b) Oxytocin synthesis b: ovine large luteal cells in vitro. Proc. Aust. Soc Reprod. Biol. 15, Abstr.

Rothchild, I. (1981) The regulation of the mammaliar corpus luteum. Recent Prog. Horm. Res. 37, 183-284

Sawyer, H.R., Abel, J.H., Jr, McClellan, M.C., Schmitz M. \& Niswender, G.D. (1979) Secretory granules anc progesterone secretion by ovine corpora lutea in vitro Endocrinology 104, 476-486.

Sokal, R.R. \& Rohlf, F.J. (1969) Biometry. W.H Freeman and Co., San Francisco.

Suter, D.E., Fletcher, P.W., Sluss, P.M. Reichert, L.E. Jr \& Niswender, G.D. (1980) Alterations in th number of ovine luteal receptors for $\mathrm{LH}$ anc progesterone secretion induced by homologous hor mone. Biol. Reprod. 22, 205-210.

Ursely, J. \& Leymarie, P. (1979) Varying response tı luteinizing hormone of two luteal cell types isolater from bovine corpus luteum. $J$. Endocr. 83, 303-310

Weinstein, P., Heath, E., Shanks, R. \& Hixon, J. (1982 Specificity of prostaglandin $\mathrm{F}_{2 \alpha}$-induced degranula tion of bovine luteal cells. Biol. Reprod. 26, Suppl. 1 $55 \mathrm{~A}$. 